\title{
STRATEGI PEMASARAN DAN PENYALURAN KUR (KREDIT USAHA RAKYAT) MIKRO PT BANK RAKYAT INDONESIA (PERSERO) TBK CABANG TANJUNG KARANG BANDAR LAMPUNG
}

\author{
Oleh: \\ Suradi \\ Nurdiansyah Ali \\ Program Studi Administrasi Bisnis, Universitas Tulang Bawang Lampung \\ E-mail: suradi0469@gmail.com
}

\begin{abstract}
ABSTRAK
Bank memegang peranan yang penting dalam perekonomian suatu negara. Dapat dikatakan bahwa pada dasarnya bank melaksanakan kegiatan distribusi karena bank bertindak sebagai perantara antara pihak pemberi pinjaman dan pihak peminjam.PT Bank Rakyat Indonesia (Persero) sebagai salah satu bank terbesar milik pemerintah yang menyalurkan kredit kepada masyarakat dirasa perlu memiliki perencanaan dan strategi yang baik untuk meningkatkan mutu pemberian kredit tersebut. Berdasarkan pemaparan tersebut, tujuan penelitian ini ialah mendeskripsikan strategi pemasaran dan penyaluran KUR Mikro pada PT Bank Rakyat Indonesia (Persero) Tbk Cabang Tanjung Karang Bandar Lampung.

Metode yang digunakan dalam penelitian ini ialah metode deskriptif kualitatif. Teknik pengumpulan data dalam penelitian ini menggunakan teknik observasi, wawancara, dan dokumentasi yang dilakukan di BRI Cabang Tanjung Karang Bandar Lampung.

Berdasarkan hasil analisis data, dapat disimpulkan bahwa strategi pemasaran yang dimiliki oleh PT BRI sebagai salah satu bank penyalur Kredit Mikro terbesar ialah dengan melakukan analisis SWOT. Selain itu, PT Bank Rakyat Indonesia (Persero) Tbk Cabang Tanjung Karang juga memiliki berbagai strategi dalam penyaluran Kredit Mikro serta mengeluarkan sejumlah kebijakan dalam mekanisme penyaluran KUR Mikronya sebagai salah satu upaya menjaga solvabilitas dan kredibilitasnya sebagai bank penyalur kredit terbesar. Sampai saat ini, BRI masih dipercaya oleh masyarakat luas untuk menyalurkan kredit kepada masyarakat sebagai upaya pemerintah untuk memberdayakan UMKM dan memajukan perekonomian masyarakat Indonesia.
\end{abstract}

Kata kunci: strategi pemasaran, strategi penyaluran, KUR Mikro BRI.

\section{PENDAHULUAN}

\subsection{Latar Belakang}

Bank memegang peranan yang penting dalam perekonomian suatu negara. Dapat dikatakan bahwa pada dasarnya bank melaksanakan kegiatan distribusi karena bank bertindak sebagai perantara antara pihak pemberi pinjaman dan pihak peminjam. Perkreditan merupakan bisnis pokok dari bank komersial. Dalam bidang inilah mereka memiliki pengalaman, keahlian, dan fleksibelitas yang memberikan kepada mereka keunggulan kompetitif dari semua lembaga keuangan 
lainnya. Penyaluran kredit ini pun memiliki manfaat-manfaat bagi bank yang bersangkutan. Muljono (1990: 57-61) menerangkan mengenai manfaat perkreditan ditinjau dari sudut kepentingan bank, antara lain memperoleh pendapatan bunga kredit, untuk menjaga solvabilitas usahanya, membantu memasarkan jasa-jasa perbankan yang lain, mempertahankan dan mengembangkan usahanya, untuk merebut pasar, dan yang terakhir adalah dengan pemberian kredit akan memungkinkan perbankan untuk mendidik para staffnya untuk mengenal kegiatan-kegiatan industri yang lain secara mendetail.

Bank Rakyat Indonesia sebagai bank terbesar di Indonesia yang dipercaya oleh masyarakat memberi pinjaman modal usaha kecil. Bank Rakyat Indonesia (Persero) tetap konsisten melakukan pelayanan kepada masyarakat kecil, diantaranya dengan memberikan fasilitas kredit kepada golongan pengusaha kecil. Usaha Mikro, Kecil, dan Menengah (UMKM) memiliki peran dan kontribusi yang cukup besar dalam perekonomian Indonesia, yaitu menyediakan lapangan kerja terbesar dan menyumbang pembentukan Produk Domestik Bruto (PDB) pada 2012. Dalam lima tahun terakhir, pemerintah mengupayakan peningkatan kontribusi UMKM dalam perekonomian. Salah satu program pemerintah dalam meningkatkan peran UMKM dalam perekonomian adalah dengan meningkatkan akses pembiayaan perbankan kepada UMKM. Pendanaan UMKM tersebut memerlukan sinergi dan kerja sama yang melibatkan berbagai kementerian/lembaga, pemerintah daerah, dan dunia usaha. Tersebut dilengkapi dengan pengembangan skema pembiayaan, basis data, dan informasi bersama, serta sistem monitoring dan evaluasi yang terpadu.
Sejak diluncurkan oleh Presiden Republik Indonesia tanggal 5 November 2007, program penjaminan kredit/pembiayaan kepada Usaha Mikro, Kecil, Menengah, dan Koperasi (UMKMK), yang selanjutnya disebut KUR (Kredit Usaha Rakyat) mendapat respon positif dari masyarakat. Berkaca dengan situasi tersebut, sesuai dengan tujuan dan peran KUR itu sendiri, maka PT Bank Rakyat Indonesia (Persero) sebagai salah satu bank terbesar milik pemerintah dirasa perlu memiliki perencanaan dan strategi yang baik untuk meningkatkan mutu pemberian KUR (Kredit Usaha Rakyat) tersebut. Salah satu strategi yang dimaksud dalam hal ini adalah strategi pemasaran dan penyaluran kredit. Strategi pemasaran dapat dinyatakan sebagai dasar tindakan yang mengarah pada kegiatan atau usaha pemasaran, dari suatu perusahaan, dalam kondisi persaingan dan lingkungan yang 2.1 Penelitian Terdahulu selalu berubah agar dapat mencapai Pada bab sebelumnya telah tujuan yang diharapkan. Menurut Philip Kotler (2004: 81), strategi pemasaran adalah pola pikir pemasaran yang akan digunakan untuk mencapai tujuan pemasarannya. Strategi pemasaran berisi strategi spesifik untuk pasar sasaran, penetapan posisi, bauran pemasaran, dan besarnya pengeluaran pemasaran. Sementara itu, Tjiptono (2002: 6) mengemukakan bahwa strategi pemasaran adalah alat fundamental yang direncanakan untuk mencapai perusahaan dengan mengembangkan keunggulan bersaing yang berkesinambungan melalui pasar yang dimasuki dan program pemasaran yang digunakan untuk melayani pasar sasaran tersebut.

\section{TINJAUAN PUSTAKA}

\subsection{Penelitian Terdahulu}

Pada bab sebelumnya telah dijelaskan bahwa terdapat penelitian serupa yang 
relevan dengan penelitian ini. Penelitian yang serupa pernah dilakukan oleh Rastri Pritidina Anjani dengan judul Strategi Pemasaran Bank dalam Meningkatkan Kredit Usaha Rakyat (KUR) pada PT Bank Lampung dengan hasil penelitian strategi pemasaran KUR (Kredit Usaha Rakyat) yang dilakukan PT Bank Lampung untuk meningkatkam KUR yaitu strategi bauran pemasaran yang terdiri atas produk, strategi harga, strategi promosi, strategi saluran distribusi, strategi sumber daya manusia, strategi proses, dan strategi bukti fisik. Selain itu penelitian yang serupa juga pernah dilakukan Yudhi Oktavianus dengan judul Strategi Pemasaran Produk Kredit Perbankan. Hasil penelitian menunjukkan Faktor kekuatan yang sangat mempengaruhi Menurut David Hunger dan dalam penentuan strategi pemasaran Bank Nagari Cabang Pekanbaru dapat dilihat dari faktor lokasi yang strategis, suku bunga bersaing, dan pelayanan prima dari karyawan.

\subsection{Manajemen Strategi}

Menurut Bambang Haryadi (2003: 3), strategi manajemen adalah suatu proses yang dirancang secara sistematis oleh manajemen untuk merumuskan strategi, menjalankan strategi dan mengevaluasi strategi dalam rangka menyediakan nilainilai yang terbaik bagi seluruh pelanggan untuk mewujudkan visi organisasi. Sementara itu, Mulyadi (2001: 40),

Manajemen strategi adalah suatu proses yang digunakan oleh manajer dan karyawan untuk merumuskan dan mengimplementasikan strategi dalam penyediaan costumer value terbaik untuk mewujudkan visi organisasi. Thomas L. Wheelen (2010: 105) strategi adalah serangkaian keputusan dan tindakan manajerial yang menentukan kinerja perusahaan dalam jangka panjang. Manajemen strategi meliputi pengamatan lingkungan, perumusan strategi (perencanaan strategis atau perencanaan jangka panjang). Implementasi strategi dan evaluasi serta pengendalian. Berdasarkan beberapa pendapat tersebut, dapat disimpulkan bahwa manajemen strategi adalah seni dan ilmu untuk formulasi, implementasi dan evaluasi keputusankeputusan yang bersifat lintas fungsional, yang digunakan sebagai panduan tindakan bagi fungsi SDM, pemasaran keuangan, produksi, dan lain-lain agar organisasi dapat mencapai tujuannya. Strategi yang baik akan memberikan gambaran tindakan utama dan pola keputusan yang akan dipilih untuk mewujudkan tujuan organisasi. Strategi juga sebagai perumusan visi dan misi suatu organisasi atau perusahaan.

\subsection{Pemasaran}

Pengertian pemasaran disederhanakan hanya sebagai kegiatan penjualan atau iklan. Sering pula pemasaran dikonotasikan sebagai periklanan. Penyederhanaan penger-tian tersebut dapat dipahami oleh karena aktivitas menonjol yang sering terlihat adalah penjualan dan iklan. Penjualan menjadi identik dengan pemasaran oleh karena ujung dari aktivitas pemasaran adalah penjualan, dan aktivitas penjualan ini lebih mudah dipahami dari pemasaran. Demikian juga dengan iklan, oleh karena iklan menjadi sajian harian bagi masyarakat baik melalui radio, televisi, majalah, koran dan media lainnya, dengan jumlah yang sangat banyak dan sering, sehingga iklan juga diidentikkan sebagai pemasaran.

Pemasaran sebagai suatu proses sosial dan manajemen yang membuat individu dan kelompok mendapat apa yang mereka inginkan dan dapatkan dari penciptaan dan pertukaran timbal balik produk dan nilai dengan orang lain (Philip Kotler dan Amstrong, 2007: 18). Secara lebih sempit, Stanton (1986: 
mendefinisikan pemasaran sebagai sistem keseluruhan dari aktivitas usaha yang ditujukan untuk merencanakan, menentukan harga, mempromosikan dan mendistribusi- kan barang dan jasa yang dapat memuaskan kebutuhan pembeli maupun pembeli potensial. Pemasaran merupakan suatu sistem keseluruhan dari aktivitas bisnis yang dirancang untuk merencanakan, menentukan harga, promosi dan mendistribusikan barang- barang yang dapat memuaskan kebutuhan dan mencapai pasar sasaran serta tujuan perusahaan.

\subsection{Strategi Pemasaran dan Bauran Pasaran}

\begin{tabular}{llll}
\multicolumn{1}{c}{ Strategi } & pemasaran & adalah & logika \\
pemasaran & dimana & unit & bisnis \\
mengharapkan & untuk & mencapai & tujuan
\end{tabular}
pemasaran. Dalam hal ini, perusahaan akan menentukan konsumen mana yang akan dipilih untuk dilayani, selanjutnya mengelompokkan pasar dalam kelompokkelompok yang lebih kecil dan melayani yang menguntungkan. Berdasarkan strategi pemasaran tersebut, selanjutnya pemasar menyusun bauran pemasaran yang terdiri dari kegiatan membuat produk, menetapkan harga, menentukan distribusi dan menentukan kegiatan promosi.

\subsection{Prinsip Dasar Kredit Secara Umum}

UU Nomor 10 tahun 1998
menyebutkan bahwa kredit adalah
penyediaan uang atau tagihan yang dapat
dipersamakan dengan itu, berdasarkan
persetujuan atau kesepakatan pinjam
meminjam antara bank dengan pihak lain
yang mewajibkan pihak peminjam untuk
melunasi utangnya setelah jangka watku
tertentu dengan pemberian bunga. Unsur-
unsur yang yang terkandung dalam
pemberian fasilitas suatu kredit menurut
Toejekam (dalam Fitria dan Sari, 2012:90)
antara lain, yaitu waktu, kepercayaan,
penyerahan, risiko, persetujuan/perjanjian.

\subsection{KUR (Kredit Usaha Rakyat)}

Kredit Usaha Rakyat (KUR) adalah layanan kredit atau pembiayaan yang diberikan oleh pemerintah melalui perbankan kepada UMKMK atau koperasi yang feasible tapi belum bankable. Feasible sendiri maksudnya adalah usaha tersebut memiliki kelayakan, potensi, prospek bisnis yang baik, dan mempunyai kemampuan untuk mengembalikan pinjaman. Beberapa usaha rakyat yang diharapkan menggunakan KUR sendiri adalah meliputi keseluruhan bentuk usaha, terutama usaha yang bergerak di sektor usaha produktif seperti pertanian, perikanan dan kelautan, perindustrian, kehutanan, dan jasa keuangan simpan pinjam. Dengan adanya layanan pinjaman KUR ini UMKM dan Koperasi akhirnya diharapkan dapat mengakses dan memanfaatkan KUR.

\subsection{Strategi dan Kebijakan Kredit dalam Manajemen Bank}

Di dalam dunia bisnis dengan tingkat persaingan yang ketat dan lingkungan yang dinamis, strategi merupakan kunci dari pencapaian keunggulan bersaing dan keberhasilan sebuah bisnis. Begitu juga bank, bank juga harus siap bersaing. Siagian (dalam Respati, 2008: xxvi) mengungkapkan bahwa manajemen stratejik adalah serangkaian keputusan dan tidakan mendasar yang dibuat oleh manajemen puncak dan diimplementasikan oleh seluruh jajaran suatu organisasi tersebut. Pemilihan strategi merupakan fokus utama dari top manajemen. Salah satu metode untuk mengembangkan alternatif strategi adalah SWOT Matrix. Dalam bukunya Manajemen Perkreditan, Mulyono (1990: 82-87), SWOT merupakan perencanaan perkreditan melalui pendekatan pasar. Orientasi perencanaan kredit ini disebut dengan customer oriented dan pola pemasarannya pun berubah dari 
seller market ke buyer market. Faktorfaktor yang menjadi pertimbangan dalam perencanaan kredit melalui pendekatan pasar ini adalah corak pemasaran, corak persaingan, corak dari para nasabah, dan corak dari produk.

\subsection{Kerangka Berpikir}

Perusahaan harus memiliki berbagai strategi pemasaran agar dapat bersaing dan mempengaruhi konsumen agar tertarik dengan produk yang ditawarkan. Begitu pula BRI sebagai salah satu bank penyalur kredit terbesar yang harus memiliki strategi pemasaran dan penyaluran kredit usaha rakyat. Selain itu, BRI juga harus mempertimbangkan peluang dan ancaman dari pesaing lain yang juga menawarkan kredit yang sama kepada masyarakat pelaku usaha. Dengan adanya strategi pemasaran dan penyaluran kredit yang baik, ditambah dengan beberapa kebijakan yang dimiliki oleh BRI, maka hal tersebut diharapkan dapat mendorong kualitas pemberian kredit yang baik oleh BRI serta mempertahankan citra BRI sebagai salah satu bank penyalur kredit terbesar.

\section{METODE PENELITIAN}

\subsection{Desain Penelitian}

Desain dalam penelitian ini adalah deskriptif kualitatif. Penelitian deskriptif adalah penelitian yang membicarakan beberapa kemungkin- an untuk memecahkan masalah dengan cara mengumpulkan data, menyusun data, menganalisis, dan menginterpretasikannya. Bodgan and Taylor (dalam Setiyadi, 2006: 219) menyatakan bahwa penelitian kualitatif merupakan prosedur penelitian yang menghasilkan data deskriptif berupa kata-kata tertulis atau lisan dari manusia dan perilakunya yang dapat diamati sehingga tujuan dari penelitian ini adalah pemahaman individu tertentu dan latar belakangnya secara utuh.

\begin{tabular}{crr}
\multicolumn{2}{c}{ Penelitian ini menggunakan } \\
pendekatan kualitatif yang bersifat
\end{tabular} mendalam karena penelitian ini ingin mengetahui mengenai strategi pemasaran dan penyaluran KUR yang diterapkan di tempat penelitian. Tempat yang digunakan dalam penelitian ini adalah PT Bank Rakyat Indonesia (Persero) Tbk Cabang Tanjung Karang Bandar Lampung. Adapun pemilihan lokasi penelitian di BRI karena BRI merupakan salah satu bank penyalur KUR Mikro terbesar di Indonesia.

Penelitian ini menggunakan unit analisis yang berfokus pada persoalan penelitian mengenai strategi pemasaran dan penyaluran Kredit Usaha Rakyat (KUR) Mikro di PT Bank Rakyat Indonesia (Persero) Tbk Cabang Tanjung Karang Bandar Lampung. Berdasarkan unit analisis yang telah dikemukakan di atas, maka pihak- pihak yang akan dijadikan informan dalam penelitian ini adalah sebagai berikut:

1. Informan kunci: Bankir dari Bank Rakyat Indonesia (Persero) Tbk Cabang Tanjung Karang Bandar Lampung.

2. Informan pendukung: Nasabah KUR Mikro BRI.

Penelitian ini bertujuan untuk mendeskripsikan hasil analisis terhadap strategi pemasaran dan penyaluran KUR (Kredit Usaha Rakyat) pada PT Bank Rakyat Indonesia Tbk Cabang Tanjung Karang Bandar Lampung.

\subsection{Data dan Sumber Data}

Data dalam penelitian ini berupa data deskriptif yang berisi strategi pemasaran dan penyaluran KUR (Kredit Usaha Rakyat) Mikro pada PT Bank Rakyat Indonesia (Persero) Tbk Cabang Tanjung Karang 
Bandar Lampung. Adapun sumber data dalam penelitian ini, yaitu segala informasi berupa dokumen maupun informasi yang diperoleh berdasarkan hasil wawancara dan observasi di PT Bank Rakyat Indonesia (Persero) Tbk Cabang Tanjung Karang Bandar Lampung selama penelitian berlangsung.

Sebagaimana yang dijelaskan bahwa penelitian ini menggunakan jenis penelitian kualitatif. Berdasarkan jenis penelitian tersebut, data yang diperoleh sangat bergantung dari informasi-informasi yang diberikan oleh informan, baik informan kunci maupun informan pendukung. Informan inti pada penelitian ini tentu saja adalah pihak terkait dari BRI Kantor Cabang Tanjung Karang Bandar Lampung. Kemudian, informan pendukung dalam penelitian ini adalah nasabah yang pernah atau sedang menerima KUR Mikro.

\subsection{Teknik Pengumpulan Data}

Ada beberapa teknik pengumpulan data yang digunakan dalam penelitian ini, yaitu sebagai berikut.

\section{Observasi}

Observasi adalah teknik pengumpulan data yang dilakukan dengan cara mengamati langsung objek yang akan diteliti. Observasi ini dilakukan untuk memperoleh gambaran nyata mengenai PT Bank Rakyat Indonesia (Persero) Tbk Cabang Tanjung Karang Bandar Lampung. Dengan demikian, penulis melakukan observasi dan pengamatan langsung ke lapangan.

\section{Wawancara}

Wawancara adalah bentuk komunikasi secara lisan baik langsung maupun tidak langsung untuk memperoleh data primer melalui pertanyaan-pertanyaan yang diajukan dan wawancara kepada responden. Dengan demikian, untuk memperoleh data yang akurat tentang obyek dan sasaran penelitian, maka penulis melakukan wawancara dengan responden yang ditentukan, yaitu wawancara dengan Kepala Cabang BRI Tanjung Karang Bandar Lampung, Manajer Pelaksana BRI Tanjung Karang Bandar Lampung, account officer BRI Cabang Tanjung Karang, mantri KUR BRI Cabang Tanjung Karang, dan nasabah KUR Mikro BRI Cabang Tanjung Karang Bandar Lampung.

\section{Dokumentasi}

Dokumentasi adalah cara yang dilakukan dengan jalan mengumpulkan dokumen-dokumen perusahaan yang berhubungan dengan penelitian ini.Dokumen ini dapat berupa data-data yang dituangkan dalam bentuk tulisan, gambar berupa grafik atau kurva, dan lain sebagainya.

\subsection{Teknik Analisis Data}

Teknik analisis data yang penulis gunakan dalam penelitian ini adalah analisis kualitatif. Adapun analisis data secara kualitatif dilakukan dengan cara menyajikan kata-kata deskriptif. Sesuai dengan maknanya, analisis kualitatif diartikan sebagai usaha analisis berdasarkan kata-kata yang disusun dan telah dirumuskan. Teknik analisis data dalam penelitian ini dianalisis dengan cara mendeskripsikan data-data hasil penelitian yang berupa dokumen perusahan dan datadata hasil wawancara serta pengamatan langsung yang telah dilakukan di PT Bank Rakyat Indonesia (Persero) Tbk Cabang Tanjung Karang Bandar Lampung.

Teknik analisis data dalam penelitian ini melalui beberapa proses, yaitu proses reading dan coding, data reduction, data 
displaying dan interpreting. Data- data yang telah didapatkan dalam penelitian tentunya memerlukan pengujian agar data yang didapat tersebut reliable (handal), kredibel, dan teruji validitasnya. Dalam penelitian ini data diuji kredibilitasnya dengan menggunakan triangulasi data atau pengecekan data dari berbagai sumber dengan berbagai cara dan waktu.

\section{HASIL PENELITIAN DAN PEMBAHASAN}

\subsection{Gambaran Umum Tempat Penelitian}

BRI (Bank Rakyat Indonesia) adalah salah satu bank milik pemerintah yang terbesar di Indonesia. Pada awalnya Bank Rakyat Indonesia didirikan di Purwokerto, Jawa Tengah oleh Raden Bei Aria Wirjaatmadja dengan nama De Poerwokertosche Hulp en Spaarbank der Inlandsche Hoofden atau "Bank Bantuan dan Simpanan Milik Kaum Priyayi Purwokerto", suatu lembaga keuangan yang melayani orang- orang berkebangsaan Indonesia (pribumi). Lembaga tersebut berdiri pada 16 Desember 1895 yang kemudian dijadikan sebagai hari kelahiran BRI.

\subsection{KUR Mikro BRI}

Kredit Usaha Rakyat (KUR) Mikro merupakan kredit modal kerja dan atau investasi dengan plafon maksimal Rp20.000.000 yang diberikan kepada usaha mikro perorangan yang memiliki usaha produktif yang dilayani oleh BRI Unit yang dimintakan penjaminan kepada Penjamin. Sumber dana KUR Mikro sepenuhnya berasal dari dana BRI. Besar prosentase penjaminan atas kredit yang disalurkan oleh BRI yang dapat dijamin oleh Penjamin yaitu sebesar 70\%, sedangkan sisa sebesar $30 \%$ merupakan bagian kerugian BRI.

\subsection{Strategi Pemasaran KUR BRI Cabang Tanjung Karang}

Dalam menjalani strategi pemasaran dibutuhkan analisis data untuk dapat menilai peluang ataupun ancaman yang mungkin akan datang. BRI menggunakan analisis SWOT untuk dapat melihat ancaman serta peluang bagi BRI. Analisis SWOT terdiri dari Strength (Kekuatan), Weakness (Kelemahan), Opportunities (Peluang), dan Threats (Ancaman). Berikut penjabarannya.

\section{Strength (Kekuatan)}

Hal-hal yang masuk ke dalam faktor strength (kekuatan) yang dimiliki oleh PT BRI cabang Tanjung Karang Bandar Lampung adalah sebagai berikut.

a. Brand

BRI merupakan salah satu bank pemerintah yang sudah dikenal oleh masyarakat umum. Nama BRI yang baik di mata masyarakat merupakan kekuatan yang dimiliki untuk dapat menyalurkan kredit KUR kepada masyarakat luas.

b. Account Officer

Account Officer yang memadai untuk menjalankan program KUR, sehingga mampu melayani setiap calon debitur.

c. Pelayanan yang Baik

Pelayanan SDM yang baik juga menjadi kekuatan karena dapat menarik minat masyarakat untuk mengajukan KUR di BRI Cabang Tanjung Karang Bandar Lampung.

d. Fasilitas Mendukung Fasilitas yang disediakan BRI Cabang Tanjung Karang cukup memadai, sehingga mampu mendukung terlaksananya promosi KUR dengan baik. 
2. Weakness (Kelemahan)

Adapun banyaknya permintaan atau pengajuan KUR (Kredit Usaha Rakyat) oleh pelaku usaha yang terus bertambah menjadi tantangan yang harus dihadapi oleh PT BRI Cabang Tanjung Karang Bandar Lampung. Pemrosesan berkas pengajuan KUR yang semakin meningkat membuat waktu antrian pemberian KUR kepada pengaju sedikit lebih lama.

\section{Opportunities (Peluang)}

Masih banyaknya pelaku UMKM$\mathrm{K}$ seperti usaha-usaha kecil, menengah, dankoperasiyang masih membutuh- kan tambahan modal usaha menjadi peluang yang besar untuk terus berjalannya program KUR.

\section{Threats (Ancaman)}

Salah satu hal yang menjadi ancaman bagi BRI adalah persaingan dengan bank lain. Persaingan dari bank lain yang juga menawarkan produk yang sama menjadi ancaman bagi BRI dalam memasarkan program KUR.

Dari analisis SWOT tersebut, BRI Cabang Tanjung Karang telah menentukan dan menjalankan strateginya dalam pemasaran KUR. Salah satu strategi yang dilakukan, yaitu dengan memanfaatkan fasilitas yang mendukung dengan membuat spanduk yang dipasang di jalan-jalan umum serta di kantor cabang dan di setiap Kantor Cabang Pembantu BRI, maupun di unit-unit kerja BRI Cabang Tanjung Karang Bandar Lampung. BRI juga membuat brosur yang berisikan tentang KUR yang bisa disebar luas ke masyarakat umum.

\subsection{Strategi Penyaluran KUR Mikro BRI}

PT Bank Rakyat Indonesia (Persero) Tbk sebagai salah satu bank penyalur KUR terbesar tentunya memiliki strategi dalam menyalurkan kreditnya. Adapun strategistrategi yang dilakukan oleh PT Bank Rakyat Indonesia (Persero) Tbk Cabang Tanjung Karang Bandar Lampung, yaitu sebagai berikut.

\subsubsection{Strategi Perencanaan KUR Mikro BRI}

Dalam menyalurkan suatu kredit/ pembiayaan, bank memiliki berbagai alasan dan tujuan yang ingin dicapai. Sebagai lembaga intermediasi, BRI mendapatkan manfaat-manfaat dalam menyalurkan kredit. Manfaat-manfaat yang didapat oleh bank menurut teori/konsep Muljono (1990: 57-59) ialah memperoleh pendapatan bunga kredit, menjaga solvabilitas usahanya, membantu memasarkan jasa-jasa perbankan yang lain, mempertahankan dan mengembangkan usahanya, merebut pasar (market share) dalam industri perbankan, dan manfaat terakhir yang didapatkan dengan pemberian kredit akan memungkinkan perbankan untuk mendidik para stafnya yang bertujuan untuk mengenal kegiatankegiatan industri yang lain secara mendetail.

\subsubsection{Kebijakan Umum}

Berbicara tentang kredit sebenarnya tidak dapat lepas dari permasalahanpermasalahan yang ada dalam suatu kegiatan perbankan. Bank pun dirasa perlu memiliki kebijakan-kebijakan kredit yang komprehensif. Begitu juga BRI dalam menyalurkan KUR Mikro memiliki kebijakan-kebijakan yang terapkan guna kelancaran, meminimalisir risiko, serta untuk kesehatan BRI. Kebijakan mengenai jangka waktu kredit yang diterapkan oleh BRI dalam penyaluran KUR Mikro untuk meminimalisir risiko.

\subsubsection{Kebijakan Prosedur Pemberian dan Pengawasan KUR Mikro}


Disamping kebijaksanaan umum, kebijaksanaan kredit memuat pedoman umum tentang prosedur pemberian dan pengawasan kredit yang wajib dipenuhi, baik oleh bank maupun oleh debitur. Pedoman prosedur pemberian dan pengawasan kredit terdiri dari standar dokumentasi, perlindungan asuransi, dan pengawasan kredit (Sutojo, 1997). Dalam setiap transaksi kredit diperlukan seperangkat strandar dokumen. Beberapa jenis dokumen tersebut merupakan bahan masukan yang penting peranannya bagi bank untuk memonitor perkembangan mutu kredit yang telah diberikan kepada debitur.

\subsubsection{Strategi Penanganan Kredit Tertentu}

Dalam penyaluran KUR Mikro, ada beberapa ketentuan yang diterapkan BRI dalam menangani kredit untuk sektor-sektor tertentu. Untuk pola angsuran, menurut sumber yang tidak dapat

dieksplisitkan diperoleh informasi bahwa apabila debitur menghendaki angsuran secara harian, mingguan, atau sesuai dengan hari pasaran atau lainnya, angsuran debitur tetap dapat diterima. Jumlah angsuran tersebut tetap harus memenuhi jumlah angsuran per bulan yang telah ditetapkan. Pedoman ini diterapkan ketika suatu unit BRI berdiri di tengah sektorsektor tertentu, sehingga cara kerja unit BRI memungkinkan untuk mengikuti sektor tersebut.

\subsubsection{Strategi Perluasan KUR Mikro BRI}

Di dalam dunia bisnis dengan tingkat persaingan yang ketat dan lingkungan yang dinamis, strategi merupakan kunci dari pencapaian keberhasilan sebuah bisnis. Begitu juga bank, juga harus siap bersaing. Keberhasilan bank dapat dilihat salah satunya ialah penyaluran kreditnya. Kredit merupakan pendapatan terbesar dari bank.
Untuk itu, bank memiliki strategi-strategi dalam mempeluas atau memperbanyak penyaluran kreditnya. BRI memang konsisten dengan bisnis mikronya. BRI sangat antusiasdalam menyalurkan KUR Mikro. Terbukti dengan semakin banyaknya unit-unit yang didirikan sampai ke pelosok dan perekrutan SDM, salah satunya Mantri dan Customer Service KUR Mikro.

\section{KESIMPULAN \\ 5.1. Kesimpulan}

Strategi pemasaran yang dilakukan oleh PT Bank Rakyat Indonesia (Persero) Tbk dalam memasarkan KUR adalah dengan melakukan analisis SWOT yang terdiri atas strenght (kekuatan), weakness (kelemahan), opportunities (peluang), dan threats (ancaman).

Dengan melakukan analisis SWOT terhadap strategi pemasaran KUR Mikro tersebut, pihak BRI dapat membuat perencanaan yang lebih matang dalam memasarkan dan menyalurkan kredit kepada rakyat.

Hal tersebut karena pihak BRI dapat mengetahui kekuatan, kelemahan, peluang, dan sesuatu yang menjadi ancaman bagi BRI yang nantinya dapat diatasi oleh BRI untuk tetap konsisten dalam memberikan kredit usaha kepada rakyat.

Penyaluran KUR Mikro oleh BRI ini memiliki dampak atau keuntungan, baik bagi BRI sebagai penyalur kredit, maupun bagi debitur KUR Mikro BRI. Keuntungan yang didapatkan oleh BRI sendiri, yaitu memperoleh pendapatan bunga kredit, menjaga solvabilitas usaha, membantu memasarkan jasa-jasa perbankan lain, mempertahankan dan mengembangkan 
usaha, serta merebut pasar dalam industri perbankan. Hal tersebut tidak terlepas dari keunggulan KUR Mikro yang dimiliki oleh BRI, yaitu KUR Mikro dengan bunga terkecil hanya sebesar 7\%. Selain itu, dengan adanya penyaluran KUR Mikro, masyarakat pelaku usaha juga memperoleh keuntungan dengan mendapatkan bantuan modal untuk mengembangkan usahanya. Dapat disimpulkan bahwa dengan adanya penyaluran KUR Mikro tersebut, BRI sebagai bank penyalur kredit usaha terbesar telah membantu majunya perekonomian di Indonesia.

\subsection{Saran}

Saran yang dapat diberikan berdasarkan penelitian ini adalah sebagai berikut:

1. Bank Rakyat Indonesia yang merupakan salah satu bank penyalur kredit terbesar hendaknya terus berinovasi dalam hal pemberian kredit kepada masyarakat untuk menjalankan UMKM-K sebagai salah satu upaya memajukan perekonomian masyarakat Indonesia.

2. Bank Rakyat Indonesia hendaknya terus mempertahankan solvabilitas dan kredibilitasnya sebagai bank yang dipercaya masyarakat luas dari segala kalangan di negeri ini.

\section{DAFTAR PUSTAKA}

Arikunto, Suharsimi. 2013. Prosedur Penelitian Suatu Pendekatan Praktik. Jakarta:

Asdi Mahasatya. Fitria, Nurul\&Raina Linda Sari. 2012. Analisis Kebijakan Pemberi Kredit Dan Pengaruh Non Performing Loan Terhadap Loan To Deposit Ratio Pada PT. Bank Rakyat Indonesia (Persero) Tbk Cabang Rantau, Aceh Tamiang (Periode
2007-2011). Jurnal Ekonomi dan Keuangan, Vol.1, (No.1).

Hunger, David dan Thomas L. Wheelen. 2003. Manajemen Strategi. Yogyakarta: Andi.

Kotler, Philip dan Gary Armstrong. 2008. Prinsip-Prinsip Pemasaran edisi 12 jilid 1. Jakarta:Erlangga.

Muljono, TeguhPudjo.1990. Manajemen Perkreditan Bagi Bank Komersiil. Edisi kedua. Yogyakarta: BPEE.

Respati,Dimas Bayu. 2008. Membangun Strategi Bisnis Melalui Fasilitas Kredit Bank dan Lingkungan Usaha dalam Meningkatkan Kinerja Perusahaan (Studi Pada Usaha Mikro Kecil dan Menengah (UMKM) sebagai Nasabah PT. Bank Rakyat Indonesia (persero) Tbk. Cabang Purwodadi). Tesis Program Magister Manajemen Universitas Diponegoro.

Setiyadi, Bambang. Metode Penelitian untuk Pengajaran Bahasa Asing (Pendekatan Kuantitatif dan Kualitatif). Yogyakarta: Graha Ilmu.

Sutojo, Siswanto. 1997. Manajemen Terapan Bank. Jakarta: Pustaka Binaman Pressindo. 